Tersedia Online di: http://ojs.umrah.ac.id/index.php/gantang/index

\title{
PENGEMBANGAN SOAL \\ MATEMATIKA MODEL PISA PADA \\ KONTEN QUANTITY UNTUK \\ MENGUKUR KEMAMPUAN \\ PEMECAHAN MASALAH \\ MATEMATIKA SISWA SEKOLAH \\ MENENGAH PERTAMA
}

\author{
Febrina Bidasari \\ febrinabidasari@gmail.com \\ Program Studi Pendidikan Matematika \\ STKIP Muhammadiyah Pagaralam
}

2017

\begin{abstract}
Abstrak
Penelitian ini bertujuan untuk: (1) menghasilkan soal-soal model PISA pada konten quantity untuk mengukur kemampuan pemecahan masalah matematika siswa SMP yang valid dan praktis, (2) mengetahui efek potensial soal-soal model PISA pada quantity terhadap kemampuan pemecahan masalah matematika siswa SMP. Metode Penelitian ini merupakan metode penelitian pengembangan. Subjek penelitian ini adalah siswa kelas IX.2 SMP Negeri 17 Palembang sebanyak 36 siswa. Teknik pengumpulan data yang digunakan dalam penelitian ini adalah walk through dan tes. Dari hasil analisis dapat disimpulkan bahwa penelitian ini telah menghasilkan (1) suatu produk soal matematika model PISA konten quantity sejumlah 12 soal berbentuk soal uraian non objektif dan dilengkapi dengan kisikisi, dan kartu soal. (2) prototype soal matematika model PISA konten quantity yang dikembangkan mempunyai efek potensial terhadap kemampuan pemecahan masalah matematika siswa dimana skor rata-rata siswa mencapai 54,64 yang dikategorikan baik.
\end{abstract}

Kata Kunci: penelitian pengembangan, soal-soal PISA konten quantity

\begin{abstract}
This study aims to: (1) produce valid and practical PISA based problems on quantity content to examine Junior High School students' problem solving skill; (2) recognize the potential effect of those problems to students' problem solving skill. Research and development was the method of the study. There were 36 ninth graders of SMP Negeri 17 Palembang as the subject of the study. Walk through and test were two ways conducted to obtain data. The result showed (1) PISA based problem on quantity content were already constructed followed by its blueprint, and question cards; (2) the prototype had potential effect towards students' problem solving skill which scored 54.64 and categorized good.
\end{abstract}

Keywords: research and development, PISA based problems on quantity content 


\section{JURNAL GANTANG. Maret 2017; II(1): 63 - 77 \\ p-ISSN. 2503-0671 \\ e-ISSN. 2548-5547}

\section{Pendahuluan}

Menurut Departemen Pendidikan Nasional (Depdiknas), salah satu tujuan pembelajaran matematika yaitu memecahkan masalah yang meliputi kemampuan memahami masalah, merancang model matematika, menyelesaikan model, dan menafsirkan solusi yang diperoleh. Kemampuan pemecahan masalah ini dirasakan sangat penting sebab hampir di semua Standar Kompetensi dan Kompetensi Dasar dijumpai.

Dengan memperhatikan tujuan pembelajaran matematika tersebut, seperti yang terdapat dalam National Council of Teachers of Mathematics (NCTM) (2000) maka pembelajaran matematika difokuskan pada kecakapan sebagai berikut:

1. Kemampuan menggunakan konsep dan ketrampilan matematis untuk memecahkan masalah (problem solving)

2. Menyampaikan

ide/gagasan (communication)

3. Memberikan alasan induktif maupun deduktif untuk membuat, mempertahankan, dan mengevaluasi argumen (reasoning)

4. Menggunakan pendekatan, keterampilan, alat, dan konsep untuk mendeskripsikan dan menganalisis data (representation)

5. Membuat pengaitan antar ide matematik, membuat model, dan mengevaluasi struktur matematika (connection)

Lima elemen ini dikenal dengan "standar proses daya matematika" atau NCTM menyebutnya dengan istilah mathematical power process standards.

Kemampuan pemecahan masalah merupakan bagian kurikulum dari matematika yang sangat penting karena dalam proses pembelajaran maupun penyelesaiannya, siswa dimungkinkan memperoleh pengalaman menggunakan pengetahuan serta keterampilan yang sudah dimiliki untuk diterapkan pada pemecahan masalah yang bersifat tidak rutin. Melalui kegiatan ini aspek-aspek kemampuan matematik penting seperti penerapan aturan pada masalah tidak rutin, penemuan pola, 64 penggeneralisasian, komunikasi matematik, dan lain-lain dapat dikembangkan secara lebih baik.

Kemampuan bersaing siswa-siswa Indonesia sampai sekarang sangat rendah dibanding dengan siswa negara lain. Meskipun tak sedikit siswa kita memenangi ajang bergengsi adu keterampilan di olimpiade matematika dan sains yang siswanya dipersiapkan khusus. Tapi secara umum kemampuan siswa Indonesia sangat memprihatinkan, berdasarkan hasil tes berstandar internasional (International Standarized Test), yaitu Trends in International Mathematics and Science Study (TIMSS) dan Programme for International Student Assesment (PISA).

Rendahnya skor matematika salah satu disebabkan faktor evaluasi atau soal yang diberikan di Indonesia hanya terbiasa di level rendah. Menurut taksonomi Bloom pembagian ranah kognitif diklasifikasikan menjadi enam tingkatan, yaitu: mengingat (C1), memahami (C2), menerapkan (C3), menganalisis (C4), mengevaluasi (C5), dan mengkreasi (C6) (Krathwohl, 2002). Di sekolah Indonesia, siswa hanya terbiasa memberikan soal pada level $\mathrm{C} 1$, $\mathrm{C} 2$, dan sebagian $\mathrm{C} 3$, sedangkan soal tes berstandar internasional PISA tidak hanya soal yang mengukur kemampuan menyelesaikan soal biasa, tetapi disini akan dilihat kemampuan siswa dalam memecahkan masalah, mulai dari menganalisisnya, memformulasikannya, dan mengkomunikasikan gagasannya kepada orang lain. Dari skala kecakapan enam level PISA lebih dari 50\% siswa Indonesia tidak mencapai level terendah, dan kemampuan pemecahan masalahnya merupakan terendah dari negara yang mengikuti.

Gambaran yang tampak dalam bidang pendidikan selama ini, pembelajaran lebih menekankan pada hafalan dan mencari satu jawaban yang benar untuk soal-soal yang diberikan, proses pemikiran tinggi termasuk berpikir kreatif jarang dilatihkan. Buku pelajaran yang dipakai siswa kalau dikaji secara jujur, semua soal yang dimuatnya kebanyakan 
hanya meliputi tugas tugas yang harus mencari satu jawaban yang benar (konvergen). Kemampuan berpikir divergen, yaitu menjajaki berbagai kemungkinan jawaban atas suatu masalah jarang diukur. Dengan demikian kemampuan intelektual anak untuk berkembang secara utuh diabaikan.

Padahal, Pemerintah dalam

Permendiknas No 19 (2006), telah mengisyaratkan bahwa pembelajaran matematika dengan hanya memberikan soalsoal konvergen menyebabkan proses pembenaran pembelajaran yang aktif dan kreatif ditelantarkan, dan dalam satu pilar belajar disebutkan bahwa belajar itu untuk membangun dan menemukan jati diri, dilaksanakan melalui proses pembelajaran yang aktif, kreatif, dan menyenangkan.

Untuk menanggulangi hal tersebut, didalam Kurikulum Tingkat Satuan Pendidikan (KTSP) yang berlaku sekarang, fokus dalam pembelajaran matematika hendaknya pendekatan pemecahan masalah. Masalah tersebut mencakup masalah tertutup dengan solusi tunggal, masalah terbuka dengan solusi tidak tunggal, dan masalah dengan berbagai cara penyelesaian.

Dari uraian di atas jelas bahwa pemecahan masalah adalah sangat penting di dalam pembelajaran matematika, khususnya masalah bilangan. Dalam keseluruhan materi matematika SMP yang terdapat dalam kurikulum termasuk materi bilangan. Dalam penilaian PISA materi bilangan ini termasuk dalam satu konten dalam PISA yaitu quantity. Soal pada konten quantity berkaitan dengan hubungan dan pola bilangan, antara lain kemampuan untuk memahami ukuran, pola bilangan dan segala sesuatu yang berhubungan dengan bilangan dalam kehidupan sehari-hari, seperti menghitung dan mengukur benda tertentu. Soal-soal pada konten quantity paling banyak diimplementasikan dalam kehidupan sehari-hari, seperti menghitung pajak, mengukur waktu, jarak dan lain-lain. Terlihat jelas bahwa soal-soal pada konten quantity penting untuk dikembangkan karena berkaitan langsung dengan kehidupan sehari-hari.
Dari hasil penelaahan peneliti terdapat soal-soal tentang bilangan yang terdapat dalam buku paket matematika pada beberapa penerbit sangat penuh dengan perhitungan. Belum ada soal yang menuntut siswa untuk mampu memecahkan masalah dalam menyelesaikan soal. Berbeda dengan soal PISA yang sangat menuntut kemampuan siswa dalam menghubungkan permasalahan yang sedang mereka hadapi dengan materi yang telah mereka pelajari di sekolah.

Berdasarkan hasil studi PISA tampak bahwa untuk masalah matematika yang menuntut kemampuan berpikir tingkat tinggi, siswa Indonesia jauh di bawah rata-rata internasional, bahkan bila dibandingkan dengan Malaysia, Singapura, Thailand. Kemampuan pemecahan masalah, kemampuan berpikir kritis dan kreatif siswa di Indonesia masih rendah, sehingga siswa lemah dalam menyelesaikan soal-soal tidak rutin yang berkaitan dengan membuktikan, menalar, menggeneralisasi, membuat konjektur, dan menentukan hubungan antara fakta-fakta yang diberikan. Soal PISA dikembangkan berdasarkan 4 konten, keempat konten tersebut meliputi: shape and space, change and relationship, quantity, dan uncertainty.

Soal-soal PISA sangat menuntut kemampuan penalaran dan pemecahan masalah. Seorang siswa dikatakan mampu menyelesaikan masalah apabila ia dapat menerapkan pengetahuan yang telah diperoleh sebelumnya kedalam situasi yang belum dikenal (Wardhani, 2005). Di dalam soal-soal PISA terdapat delapan ciri kemampuan kognitif matematika yaitu thinking and reasoning, argumentation, communication, modelling, problem posing and solving, representation, using symbolic, formal, and technical language and operations, and use of aids and tools.

Penelitian pengembangan soal PISA pernah dilakukan Devi (2011) mengenai pengembangan soal matematika model PISA untuk mengukur kemampuan komunikasi matematis siswa SD. Namun penelitian ini belum membahas pengembangan soal PISA pada konten quantity untuk siswa SMP. 
JURNAL GANTANG. Maret 2017; II(1): 63 - 77

p-ISSN. 2503-0671

e-ISSN. 2548-5547

1. Programme for International Student Assessment (PISA)

PISA adalah studi tentang program penilaian siswa tingkat internasional yang diselenggarakan oleh organisation for Economic Cooperation and Development (OECD) atau organisasi untuk kerjasama ekonomi dan pembangunan. PISA bertujuan untuk menilai sejauh mana siswa yang duduk di akhir tahun pendidikan dasar (siswa berusia 15 tahun) telah menguasai pengetahuan dan keterampilan yang penting untuk berpartisipasi sebagai warga negara atau anggota masyarakat yang membangun dan bertanggung jawab. Hal-hal yang dinilai dalam studi PISA meliputi literasi matematika, literasi membaca, dan literasi sains. Pada tahun 2012 akan ditambahkan satu mata ujian lagi berupa literasi keuangan (Wardhani, 2011).

Indonesia telah berpartisipasi sejak PISA pertama di tahun 2000, namun hasil yang dicapai siswa Indonesia masih jauh dari memuaskan. Siswa Indonesia menempati ranking 39 dari 41 negara dalam PISA Matematika tahun 2000. Pada PISA 2003 siswa Indonesia menduduki ranking 38 dari 40 negara. Pada PISA 2006 dan PISA 2009, secara berturut-turut siswa Indonesia pada posisi 50 dari 57 negara dan 61 dari 65 negara.

Tujuan dari studi PISA adalah untuk menguji dan membandingkan prestasi anak-anak sekolah di seluruh dunia, dengan maksud untuk meningkatkan metode-metode pendidikan dan hasil-hasilnya. Di dalam Undang-Undang Sistem Pendidikan Nasional No. 20 tahun 2003 dijelaskan tentang fungsi dan tujuan pendidikan yaitu untuk mengembangkan kemampuan dan membentuk watak serta peradapan bangsa yang bermartabat dalam rangka mencerdaskan kehidupan bangsa, sedangkan tujuannya adalah mengembangkan potensi peserta didik agar menjadi manusia yang beriman dan bertakwa kepada Tuhan Yang Maha Esa, berakhlak mulia, sehat, berilmu, cakap, mandiri, kreatif, dan menjadi warga negara yang demokratis serta tanggung jawab.
2. Karakteristik Studi PISA

PISA mengukur kemampuan peserta didik pada akhir usia wajib belajar untuk mengetahui kesiapan peserta didik menghadapi tantangan masyarakat pengetahuan dewasa ini.

Penilaian PISA dibedakan dari penilaian lainnya yaitu:

a) PISA berorientasi pada kebijakan desain dan metode penilaian dan pelaporan disesuaikan dengan kebutuhan masingmasing negara peserta PISA.

b) PISA menggunakan pendekatan literasi inovatif

c) Konsep belajar dalam PISA berhubungan dengan konsep belajar sepanjang hayat.

d) Pelaksanaan PISA teratur dalam rentang waktu tertentu yang memungkinkan negaranegara peserta untuk memonitor kemajuan mereka sesuai dengan tujuan belajar yang diterapkan.

e) Cakupan pelaksanaan dalam PISA sangat luas (Hayat \& Yusuf, 2010:199).

3. Level Kemampuan Pemecahan Masalah dalam PISA

Selanjutnya PISA juga merumuskan secara jelas tingkat kemampuan pemecahan masalah yang terbagi dalam tiga level yaitu: (OECD, 2004)

Level 1: Pemecahan masalah yang dasar

Kompetensi pemecahan masalah adalah siswa mampu menyelesaikan masalah yang berhubungan dengan data dari suatu sumber dan informasinya terdefinisi dengan jelas; siswa memahami sifat-sifat dari masalah tersebut serta menempatkan dan menemukan informasi yang berhubungan dengan masalah tersebut; siswa pada level 1 ini juga mampu mengubah informasi yang ada dalam masalah tersebut dan menampilkannya dengan cara yang berbeda. Misalnya mengambil informasi dari tabel yang selanjutnya menampilkan dalam bentuk gambar atau grafik; diharapkan juga siswa dapat menerapkan informasi untuk memeriksa keterbatasan dari kondisi yang didefinisikan dengan baik dalam masalah; namun, siswa pada level ini biasanya tidak secara langsung berhasil 
mengatasi masalah yang melibatkan data lebih dari satu sumber atau menuntun mereka untuk memberikan alasan berdasarkan informasi yang diberikan

Level 2: Pemecahan masalah yang menentukan keputusan dan bernalar

Kompetensi Pemecahan Masalah adalah kemampuan pemecahan masalah siswa, proses penalaran dan analitik serta penyelesaian masalah yang membutuhkan keterampilan membuat keputusan; siswa dapat menerapkan berbagai jenis penalaran untuk menganalisis situasi dan menyelesaikan masalah yang membutuhkan untuk membuat keputusan diantara beberapa alternatif; untuk menganalisis sebuah sistem atau membuat keputusan, siswa menggabungkan dan mensintesis informasi dari berbagai sumber; siswa mampu menggabungkan berbagai bentuk representasi (misalnya bahasa yang formal, informasi yang ada pada grafik), menangani representasi yang tidak biasa (misalnya menyatakan dalam bahasa pemograman atau diagram alir terkait dengan susunan struktur atau mekanis komponen) dan menarik kesimpulan berdasarkan dua atau lebih sumber informasi

Level 3: Pemecahan masalah yang komunikatif dan cemerlang

Kompetensi pemecahan masalah adalah Siswa mampu melakukan pendekatan secara sistematis, membangun representasi mereka sendiri yang digunakan untuk membantu mereka dalam menyelesaikan permasalahan; siswa mampu membuktikan bahwa solusi yang mereka berikan memenuhi/sesuai dengan yang diharapkan oleh soal; siswa mengkomunikasikan solusi mereka menggunakan pernyataan tertulis yang akurat dan menggunakan representasi-representasi yang lain; siswa cenderung mempertimbangkan dan menangani sejumlah besar kondisi seperti memperhitungkan batasan yang bersifat sementara, dan batasan lainnya; masalah yang diberikan pada level ini bersifat komplek yang menuntun dan mengharuskan siswa mengatur pekerjaan mereka dan mengembangkan penyelesaian yang unik
Ketiga level pemecahan masalah tersebut untuk selanjutnya diramu dan berbaur dalam soal-soal PISA yang disajikan dalam enam level kemampuan matematika secara umum. PISA sebagai studi/program Internasional juga mengukur kemampuan memecahkan masalah sehingga memudahkan penilaian terhadap kemampuan-kemampuan pemecahan masalah pada setiap level PISA. Adapun menspesifikasikan kemampuankemampuan pemecahan masalah pada setiap level soal yang diujikan dalam PISA sebagaimana yang dikutip dalam (Econtentplus, 2009) sebagai berikut:

a. Soal Level 1

Menyelesaikan permasalahan yang jelas dan langsung

b. Soal Level 2

Menarik kesimpulan secara langsung

c. Soal Level 3

Menggunakan strategi pemecahan masalah yang sederhana

d. Soal Level 4

Mampu bekerja dengan batasan-batasan dan asumsi-asumsi

e. Soal Level 5

Memilih, membandingkan, dan mengevaluasi strategi pemecahan masalah yang sesuai

f. Soal Level 6

Siswa dapat menyelidiki dan memodelkan permasalahan pada situasi kompleks.

\section{Metode Penelitian}

Subjek penelitian adalah siswa kelas IX SMP Negeri 17 Palembang.

Metode Penelitian

1. Prosedur Penelitian

1) Preliminary

i. Persiapan

Tahap analisis ini merupakan langkah awal penelitian pengembangan. Tahap ini dilakukan analisis terhadap kompetensi dasar soal yang dikembangkan, analisis terhadap peserta didik serta mengobservasi kondisi kelas dan sekolah yang dijadikan sebagai tempat penelitian, mengadakan 
persiapan-persiapan lainnya seperti mengatur jadwal penelitian dan prosedur kerjasama dengan guru kelas.

ii. Pendesainan

$$
\text { Pada tahap ini peniliti }
$$
mendesain perangkat tes, meliputi pendesainan kisi-kisi dan soal-soal PISA konten quantity. Desain instrumen penilaian yang meliputi membuat kisikisi, penulisan indikator, penulisan instrumen dengan didasarkan pada kriteria soal-soal PISA. Desain produk ini sebagai prototype 1. Prototype $1 \mathrm{ini}$ fokus pada tiga karakteristik yaitu konten, konstruk, dan bahasa.

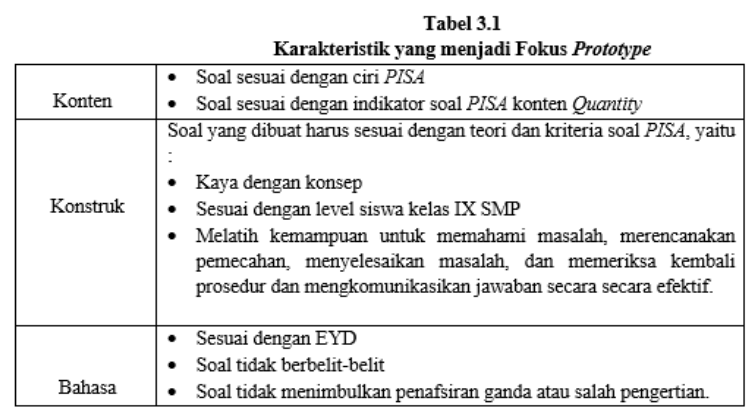

Ketiga karakteristik ini divalidasi oleh pakar (expert review ).

2) Tahap Formatif Evaluation

\section{$i$. Self Evaluation}

Pada tahap ini dilakukan penilaian oleh diri sendiri terhadap hasil desain soal-soal model PISA pada konten quantity yang dibuat oleh peneliti.

\section{ii. Expert Reviews}

Pada tahap ini desain soal yang dibuat oleh peneliti dikonsultasikan kepada pakar untuk divalidasi yang meliputi validitas konten, validitas konstruk, dan validitas bahasa. Saran dan komentar dari validator ini dijadikan sebagai masukan untuk memperbaiki desain yang telah dibuat. Tahap ini juga dinamakan sebagai uji validasi. Uji validasi dengan memfokuskan kepada tiga krakakteristik (konten, konstruk, dan bahasa) dikenal dengan teknik triangulasi yaitu teknik validasi data yang memanfaatkan sesuatu yang lain diluar pakar dan sejawat, untuk keperluan pengecekan dan sebagai pembanding yang menjadi dasar untuk merevisi instrumen.

iii. One-to-one

Pada tahap One-to-One ini peneliti mengambil 3 orang siswa sebagai tester. Hasil jawaban dan komentar siswa digunakan untuk merevisi desain soal-soal model PISA yang telah dibuat peneliti. Apabila perangkat soal masih dianggap belum valid maka harus diteliti kembali. Hasil revisi prototype I dinamakan dengan prototype II. Setelah uji coba One-toOne, dilaksanakan uji validasi dan perhitungan reliabilitas terhadap soal, yang diujikan kepada siswa non subjek penelitian

iv. Small Group (Kelompok Kecil)

Pada tahap ini dilakukan ujicoba dengan menggunakan prototype II, yaitu prototype yang telah direvisi atau diperbaiki melalui saran komentar pakar dan tester. Prototype II ini diberikan pada kelompok kecil non subjek penelitian yang beranggotakan 6 orang siswa kelas IX SMP untuk menyelesaikan soal-soal yang telah didesain. Siswa-siswa tersebut memiliki karakteristik yang akan dijadikan sasaran penelitian. Selanjutnya mereka diminta untuk memberikan tanggapan terhadap soal-soal model PISA yang diujikan.

Berdasarkan hasil tes dan tanggapan siswa inilah soal direvisi dan diperbaiki lagi. Pada tahap ini juga dievaluasi tampilan dan penggunaan soal guna melihat tanggapan, penilaian, dan kepraktisan soal-soal tersebut dan hasilnya sebagai masukan untuk merevisi desain soal ke tahap 
berikutnya. Tahap berikutnya disebut prototype III.

\section{v. Field Test}

Saran-saran serta hasil uji coba pada prototype II dijadikan dasar untuk merevisi desain prototype II. Hasil revisi disebut prototype III, diujicobakan ke subjek penelitian (field test), yaitu siswa SMP Negeri 17 Palembang kelas IX yang menjadi subjek penelitian.

Produk yang telah diujicobakan pada field test haruslah yang telah memenuhi kriteria kualitas. Akker (1992:126) mengemukakan bahwa tiga kriteria kualitas adalah: validitas (dari pakar, teman sejawat, dan guru matematika), kepraktisan (penggunaannya mudah dan dapat digunakan untuk mengukur kemampuan pemecahan masalah matematika siswa), dan efektifitas (bagaimana kemampuan pemecahan masalah siswa pada soal model PISA pada konten quantity.

2. Teknik dan Istrumen Pengumpulan data

Sesuai dengan jenis data yang ingin diperoleh dalam penelitian ini, maka instrumen yang digunakan adalah soal-soal matematika model PISA dan dokumen hasil jawaban siswa dalam menyelesaikan soal matematika model PISA pada konten quantity untuk mengukur kemampuan pemecahan masalah matematika siswa sekolah Menengah Pertama. Teknik pengumpulan data yang digunakan dalam penelitian ini adalah:

\section{a) Data dari Expert Review (Uji Pakar)}

Teknik yang digunakan adalah Walk through yaitu suatu kegiatan pengumpulan data dengan cara mencatat masukan berupa saran, pada saat pakar melakukan uji validitas terhadap instrumen yang kita kembangkan. Pakar melakukan uji validitas soal yang meliputi isi (content), konstruk, dan bahasa terhadap instrumen yang dikembangkan. Dari hasil kegiatan ini diperoleh masukan dan saran yang digunakan untuk memperbaiki instrumen yang dikembangkan. Prosedur yang digunakan anatara lain:
- Peneliti memberikan desain prototype yang telah dikembangkan,

- Pakar atau ahli mengevaluasi semua materi dan memberikan saran dan komentarnya terhadap prototype yang diberikan peneliti,

- Peneliti melakukan perbaikan terhadap prototype, dengan mempertimbangkan saran dan komentar dari pakar.

Berikut dijelaskan jumlah pakar, waktu, fokus serta metode dan prosedur yang digunakan serta lembar validasi yang akan diisi oleh validator sesuai dengan hasil evaluasi mereka terhadap isi, konstruk dan bahasa.

Tabel 3.2
Gambaran pakar tentang soal-soal PISA pada konten Quantity
\begin{tabular}{|l|l|}
\hline Jumlah pakar & 3 orang pakar (ahli) \\
\hline Waktu pelaksanaan & Dikonsultasikan dengan pakar \\
\hline Fokus & $\begin{array}{l}\text { Kevalidan dari soal-soal model PISA pada konten Quantity } \\
\text { meliputi analisis terhadap bahasa, kalimat dan kata yang } \\
\text { digunakan dalam soal-soal yang didesain. }\end{array}$ \\
\hline Metode & Walk through \\
\hline Prosedur & $\begin{array}{l}\text { Peneliti memberikan soal-soal model PISA pada konten } \\
\text { Quantity yang telah dibuat oleh peneliti, kemudian pakar } \\
\text { mengevaluasi setiap soal. Saran dari pakar kemudian dicatat } \\
\text { dan dijadikan masukan sebagai bahan untuk merevisi soal. }\end{array}$ \\
\hline
\end{tabular}

Format saran dan masukan dari pakar untuk pengembangan soal dan keputusan revisi disajikan sebagai berikut

Tabel 3.3

Saran/komentar dan Keputusan Revisi dari Pakar

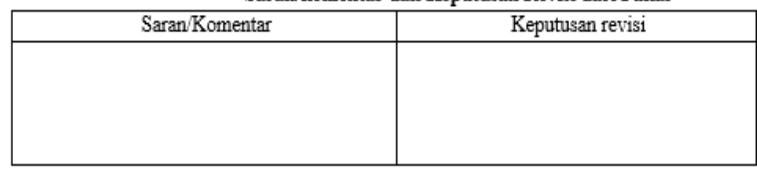

b) Data hasil one-to-one

Data dari hasil one-to-one diperoleh dengan memberikan soal tersebut kepada satu orang tester, kemudian hasil jawaban dan komentarnya dijadikan dasar untuk memperbaiki prototype. Adapun beberapa hal yang harus dikomentari tester yaitu mengenai kejelasan soal, pemahamnnya terhadap soal, dan kesulitannya dalam memahami soal, serta gambar-gambar pada soal apakah dapat membantu dalam memahami soal. Analisis yang dilakukan terhadap komentar/saran dan lembar jawaban siswa kelas IX SMP yang terdiri dari tiga orang siswa dengan kemampuan matematika tinggi, sedang, dan rendah. Analisis dokumen pada one-to-one untuk 
melihat kepraktisan soal-soal matematika model PISA konten quantity yang dibuat oleh peneliti. Hasil setelah uji coba One-toOne, dilaksanakan uji validasi dan perhitungan reliabilitas terhadap soal, yang diujikan kepada siswa non subjek penelitian.

c) Data hasil small group

Data small group didapat dari hasil pekerjaan siswa, dimana soal diujicobakan kepada 6 orang siswa diluar subjek penelitian. Analisis dilakukan terhadap komentar/saran dan lembar jawaban siswa kelas IX SMP yang bukan subjek penelitian yang terdiri dari 6 orang dengan kemampuan matematika tinggi ( 2 orang siswa), sedang (2 orang siswa), dan rendah (2 orang siswa). Analisis dokumen pada small group ini juga melihat kepraktisan soal matematika model PISA yang berupa kejelasan dan keterbacaan soal.

d) Data hasil field test

Data hasil uji lapangan (field test) diperoleh dengan mengujicobakan soal-soal PISA konten quantity tersebut kepada subjek penelitian, kemudian hasil jawaban siswa diberi skor sesuai dengan sistem penskoran.

3. Teknik Analisis Data

1) Analisis deskriptif

- Analisis deskriptif digunakan untuk menganalisis data validitas ahli dengan cara merivisi berdasarkan wawancara atau catatan validator, dan pemeriksaan dokumen soal model PISA oleh validator guru. Hasil dari analisis akan digunakan untuk merevisi soal-soal yang dibuat oleh peneliti.

- Analisis desktiptif ini juga digunakan untuk menganalisis data kepraktisan soalsoal model PISA, yang didapat berdasarkan pengamatan dan temukan selama siswa small group untuk mengerjakan soal-soal. Hasil dari analisis ini juga akan digunakan untuk merevisi soal-soal yang dibuat oleh peneliti.

2) Analisis Data Tes Soal Model PISA
Analisis data tes soal-soal matematika model PISA pada konten quantity digunakan untuk mengukur kemampuan pemecahan masalah matematika siswa Sekolah Menengah Pertama dan efek potensial soal matematika model PISA pada konten quantity terhadap kemampuan pemecahan masalah siswa.

Untuk mengukur kemampuan pemecahan masalah matematika siswa Sekolah Menengah Pertama dapat diketahui berdasarkan hasil tes soal-soal matematika model PISA pada konten quantity yang diberikan kepada siswa. Kemudian akan dilakukan penyekoran terhadap jawaban siswa. Sistem penyekoran kemampuan tersebut dibuat seperti pada Tabel berikut:

\begin{tabular}{|c|c|}
\hline Kemampuan Memahami Masalah & SKOR \\
\hline Tidak memahami masalah & 0 \\
\hline Salah mengimterprestasikan sebagaian soal atau mengabaikan kondisi awal & $\overline{1}$ \\
\hline Memahami masalah atau soal dengan lengkap. & 2 \\
\hline Kemampuan Merencanakan Penyelesaian Masalah & SKOR \\
\hline Tidak ada strategi sama sekali & 0 \\
\hline $\begin{array}{l}\text { Menggunakan satu strategi yang kurang dapat dilaksanakan dan tidak dapat } \\
\text { melanjutkan }\end{array}$ & 1 \\
\hline $\begin{array}{l}\text { Menggunakan sebagaian strategi yang benar tetapi mengarahkan pada } \\
\text { jawaban yang salah atau tidak mencoba strategi lain }\end{array}$ & 2 \\
\hline Menggunakan strategi yang mengarah ke solusi benar. & 3 \\
\hline Kemampuan Melaksanakan Penyelesaian Masalah & SKOR \\
\hline Tidak ada solusi sama sekali & 0 \\
\hline Menggunakan beberapa prosedur yang mengarah ke solusi benar & 1 \\
\hline Hasil salah atau sebagian salah, karena salah perhitungan & 2 \\
\hline Proses dan hasil benar & 3 \\
\hline Kemampuan Memeriksa Hasil yang Diperoleh & SKOR \\
\hline Tidak mendapatkan jawaban & 0 \\
\hline Mendapatkan dan menyatakan jawaban, tapi tidak lengkap & 1 \\
\hline Mendapatkan dan menyatakan jawaban dengan benar dan lengkap & 2 \\
\hline
\end{tabular}

Skor kemampuan pemecahan masalah matematika siswa adalah jumlah skor yang diperoleh siswa dalam menyelesaikan soal matematika tipe PISA pada konten quantity. Masing-masing soal dari jumlah soal sebanyak 10 butir mengandung empat indikator pemecahan masalah. Sehingga skor maksimumnya adalah 100, dan skor minimal $0 \times 10=0$, sehingga interval skor rata-rata kemampuan 
pemecahan masalah matematika adalah 100 $0=100$. Kemudian, peneliti membagi interval ini menjadi 4 selang rata-rata 25 .

Skor akhir siswa diperoleh dengan menganalisis data hasil tes, kemudian skor akhir siswa ini dikonversikan dalam data kualitatif untuk menentukan kategori tingkat kemampuan pemecahan masalah matematika siswa sebagai berikut:

Tabel 3.5 Kategori Tingkat Kemampuan Pemecahan Masalah Matematika

\begin{tabular}{|c|c|}
\hline Nilai & Kategori \\
\hline $76-100$ & Sangat Baik \\
$51-75$ & Baik \\
$26-50$ & Cukup \\
$0-25$ & Kurang \\
\hline
\end{tabular}

\section{1) Uji Validitas dan Perhitungan Reliabilitas}

Menurut Sugiyono (2007) dengan menggunakan instumen yang valid dan reliabel dalam pengumpulan data, maka diharapkan hasil penelitian ini akan menjadi valid dan reliabel. Jadi, instrumen yang valid dan reliabel merupakan syarat mendapatkan hasil penelitian yang valid dan reliabel. Hal ini tidak berarti bahwa dengan menggunakan instrumen yang telah teruji validitas dan reliablitasnya, otomatis hasil (data) penelitian menjadi valid dan reliabel. Hal ini masih akan dipengaruhi oleh kondisi objek yang diteliti dan kemampuan orang yang mneggunakan instrumen.

\section{a. Validitas Butir Soal}

Validitas adalah suatu ukuran yang menunjukkan tingkat kevalidan atau kesahihan suatu instrumen. Untuk menghitung validitas item soal digunakan rumus korelasi Product moment (Arikunto, 1999). Dengan taraf nyata $\alpha$ $0,05 \%$, jika $t_{\left(1-1 / 2^{\alpha}\right)(n-2)}<t_{\text {hitung maka }}$ butir soal dikatakan valid.

\section{b. Reliabilitas}

Reliabilitas digunakan untuk menunjukkan bahwa suatu instrumen cukup dapat dipercaya untuk digunakan sebagai alat pengumpul data karena instrumen tersebut sudah baik. (Arikunto, 1999). Untuk perhitungan reliabilitas dalam penelitian ini digunakan rumus alpha. (Arikunto, 1999)

\section{Kriteria Keberhasilan}

Kriteria keberhasilan yang diharapkan dalam penelitian ini adalah dihasilkannya produk soal matematika tipe PISA pada konten quantity yang valid, praktis, dan efektif terhadap kemampuan pemecahan masalah matematis siswa Sekolah Menengah Pertama.

Kevalidan dari soal matematika tipe PISA pada konten quantity diperoleh hasil validasi dari pakar yang berupa saran, komentar, dan One-to-one serta hasil analisis validasi butir soal dan reliabilitas soal pada uji coba butir soal.

Kevalidan berarti soal matematika tipe PISA pada konten quantity sesuai dengan apa yang diukur. Dalam penelitian ini kevalidan tersebut adalah valid jika terkategori dengan baik sesuai dengan kriteria yang ditetapkan yaitu konten, konstruk, dan bahasa. Dan kevalidan dalam penelitian ini juga berarti valid berdasarkan analisis validasi butir soal dan reliabilitas soal pada uji coba butir soal.

Kepraktisan soal matematika tipe PISA pada konten quantity diamati dari hasil pengamatan small group. Kepraktisan berarti mudah dipakai oleh pengguna, soal matematika tipe PISA pada konten quantity dikategorikan praktis jika soal sesuai dengan kriteria sebagai berikut:

a) Sesuai dengan tingkat pendidikan siswa yaitu siswa SMP

b) Konteks yang diberikan mudah dipahami siswa

c) Mudah dibaca dan tidak menimbulkan penafsiran ganda 
JURNAL GANTANG. Maret 2017; II(1): 63 - 77

p-ISSN. 2503-0671

e-ISSN. 2548-5547

\section{Hasil dan Pembahasan}

Berdasarkan

langkah-langkah

pengembangan soal sebagaimana yang telah diuraikan pada bab sebelumnya. Ada 12 soal PISA konten quantity dari hasil pengembangan peneliti. Tahapan pengembangan tersebut sebagai berikut yaitu tahap formative evaluation yang meliputi self evaluation, prototyping (expert reviews dan one-to-one, dan small group), serta field test.

\section{Self Evaluation}

Tahap ini meliputi analisis siswa, analisis kurikulum, analisis soal-soal PISA dan pendesainan soal sebagaimana diuraikan sebagai berikut:

a. Analisis

- Analisis Siswa

Analisis siswa bertujuan untuk mengetahui kemampuan matematika siswa dalam memilih subjek penelitian, yaitu siswa kelas IX SMP Negeri 17 Palembang dengan tinggi kemampuan yang hetegoren. Informasi tersebut diberikan secara langsung oleh wakil kepala sekolah bagian kurikulum.

- Analisis Kurikulum

Pada tahap ini, yang dilakukan adalah mengidentifikasi materi pembelajaran matematika SMP, Standar Isi pembelajaran matematika untuk tingkat menengah pertama meliputi aljabar, bilangan, geometri dan pengukuran, serta pengolahan data. Dari analisis kurikulum, konten quantity termasuk ke dalam aspek Aljabar dan Bilangan. Materi-materi yang dimaksud tersebar pada materi SMP, yaitu:

Kompetensi dasar dan indikator yang sesuai dengan KTSP pada satuan pendidikan SMP Negeri 17 Palembang hanyalah sebagai pembanding bagi materi soal-soal model PISA konten quantity mengingat bahwa desain soal tersebut tidak dibuat berdasarkan kurikulum yang ada pada satuan pendidikan tetapi hanyalah berdasarkan situasi dan konten yang telah diuraikan pada PISA. Ada beberapa persamaan yang didapat, sehingga peneliti mendesain soal dengan mengadaptasi antara kerangka soal PISA dan materi pada KTSP SMP. b. Desain

Desain soal matematika model PISA model quantity yang dibuat meliputi:

i. Kisi-kisi soal

ii. Kartu Soal

iii. Soal

iv. Kunci jawaban

Pada tahap awal ini, peneliti mengembangkan soal matematika model PISA konten quantity yang terdiri dari 12 soal. Peneliti juga membuat kisi-kisi soal, kartu soal, dan kunci jawaban, sebagai bahan pertimbangan bagi validator untuk memeriksa validasi soal matematika model PISA konten quantity. Desain soal yang dibuat peneliti sebanyak 12 soal PISA konten quantity.

\section{Prototyping}

\section{- Expert Reviews}

Pada tahap ini soal divalidasi dari segi konten, konstruk dan bahasa, dikonsultasikan dan diperiksa oleh Ratu Ilma Indra Putri, dan Somakim. Selain itu, penulis meminta pendapat dari dosen yang lain dan teman sejawat yang sudah berpengalaman dalam pendidikan matematika sebagai validator.

Adapun saran dan komentar dari para pakar dan teman sejawat adalah sebagai berikut

Tabel 4.1

Saran dan Komentar Validator terhadap Soal

\begin{tabular}{|c|c|}
\hline Validator & Saran/Komentar \\
\hline Sutarto Hadi & $\begin{array}{l}\text { - Semua soal bagus dan sesuai dengan Standar PISA } \\
\text { - Kalimat yang digunakan juga sudah sesuai dengan } \\
\text { kaidah Bahasa Indonesia, mudah dipahami, dan } \\
\text { tidak menimbulkan makna ganda } \\
\text { - Soal terakhir tentang menara, ada kata yang tidak } \\
\text { menyambung, di sana tertulis menara "tersebut", } \\
\text { kata "tersebut" merujuk kemana? Tidak jelas, } \\
\text { sepertinya ada kalimat sebelumnya. } \\
\text { - Mengenai konstruk soal, sangat bagus, terutama } \\
\text { karena soalnya merupakan soal pemecahan } \\
\text { masalah. Ini sangat baik untuk melihat bagaimana } \\
\text { strategi pemecahan masalah yang digunakan } \\
\text { siswa. }\end{array}$ \\
\hline Erna Purwantini & $\begin{array}{l}\text { - Soal sesuai dengan kemampuan siswa } \\
\text { - Soal sudah sesuai dengan KD } \\
\text { - Perbaiki kalimat sesuai dengan EYD }\end{array}$ \\
\hline Kamaliyah & $\begin{array}{l}\text { - Soal nomor , } 1,4,5,11 \text {, dan } 12 \text { perbaiki kalimat } \\
\text { - Soal nomor } 11 \text {, penulisan } R p \text { tanpa titik, dan spasi. }\end{array}$ \\
\hline
\end{tabular}

diambil langkah tindakan revisi sebagai berikut

Berdasarkan komentar dan saran dari pakar dan dan teman sejawat tersebut, maka diambil langkah tindakan revisi sebagai berikut 
Tabel 4.2

Saran/Komentar Validator serta keputusan Revisi

\begin{tabular}{|c|c|}
\hline Saran/Komentar & Keputusan Revisi \\
\hline - Perbaiki penulisan kalimat dan & •Penulisan kalimat dan penggunaan tanda baca \\
penggunaan tanda baca pada & pada soal diperbaiki \\
setiap soal & \\
- Soal terakhir tentang menara, ada & - Kata "tersebut" pada soal nomor 12 diganti \\
kata yang tidak menyambung, di & menjadi "pada gambar di atas" \\
sana tertulis manara " tersebut", & \\
kata "tersebut" merujuk kemana? & \\
Tidak jelas, sepertinya ada kalimat & \\
sebelumnya. & \\
\hline
\end{tabular}

- Uji Coba Pada One-to-One

Pada tahap ini, soal yang dikembangkan pada prototype I diujikan kepada tiga orang siswa dengan kemampuan yang berbeda. Secara keseluruhan dari analisis terhadap lembar jawaban siswa, dapat terlihat bahwa siswa tersebut sudah dapat memahami soal dengan baik, dapat membuat rencana strategi penyelesaian yang relevan sehingga didapat hasil akhir yang benar. Ini dapat diartikan bahwa prototype I tersebut sudah praktis untuk siswa. Walaupun ada beberapa soal yang belum dapat diselesaikan dengan benar oleh siswa. Ada beberapa kesalahan dalam melakukan perhitungan, dan kesalahan dalam menginterprestasikan soal. Adapun Saran dan Komentar siswa diuraikan pada Tabel 4.3 berikut: Tabel 4.3. Saran dan Komentar Siswa terhadap Soal serta Keputusan Langkah Tindakan
Revisi

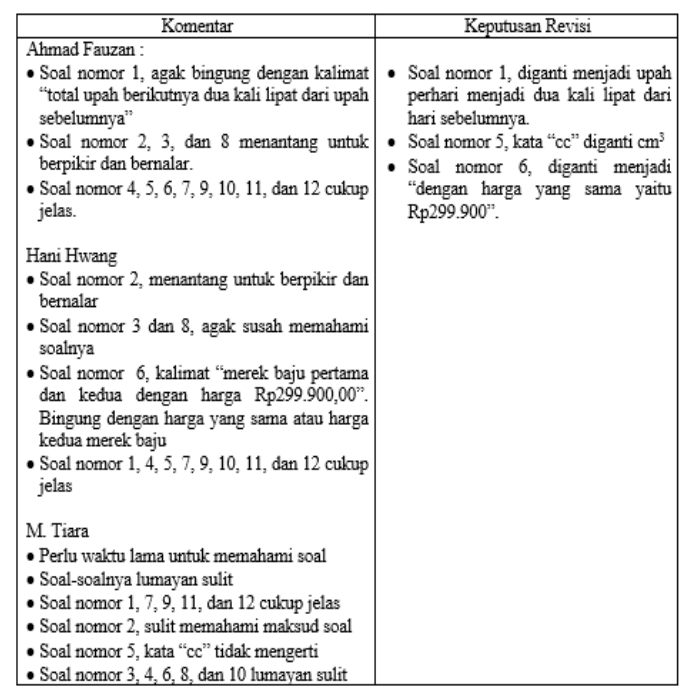

Tabe1 4.4. Hasil Jawaban Siswa pada One-to-One Evaluation

\begin{tabular}{|l|c|c|c|c|c|c|c|c|c|c|c|c|}
\hline Nama Siswa Soal & 1 & 2 & 3 & 4 & 5 & 6 & 7 & 8 & 9 & 10 & 11 & 12 \\
\hline Ahmad Fauzan & $\checkmark$ & $\checkmark *$ & $\sqrt{*}$ & $\checkmark$ & $\checkmark$ & $\checkmark$ & $\checkmark *$ & $\checkmark *$ & $\checkmark$ & $\checkmark$ & $\checkmark *$ & $\checkmark$ \\
\hline Hani Hwang & $\checkmark$ & $\checkmark *$ & $\times$ & $\checkmark$ & $\checkmark$ & $\checkmark$ & $\checkmark *$ & $\times$ & $\checkmark$ & $\times$ & $\checkmark *$ & $\checkmark$ \\
\hline M. . iara & $\times$ & $\times$ & $\times$ & $\times$ & $\checkmark$ & $\times$ & $\checkmark *$ & $\times$ & $\times$ & $\times$ & $\checkmark *$ & $\times$ \\
\hline
\end{tabular}

Tabel 4.4 menunjukkan kemampuan siswa dalam menyelesaikan soal-soal matematika model PISA yang diberikan yang dapat membantu mengidentifikasi pada soal yang mana siswa mengalami kesulitan.

Revisi soal prototype I berdasarkan expert reviews dan One-to-One Evaluation seperti yang diuraikan di atas menghasilkan prototype II yang terdiri dari 12 soal. Setelah itu dilaksanakan uji validasi dan perhitungan reliabilitas terhadap soal, yang diujikan kepada siswa non subjek penelitian.

- Uji Validitas dan Perhitungan Butir Soal

Langkah selanjutnya yang dilakukan peneliti adalah melakukan analisis butir soal yang ada pada prototype II untuk menguji validitas dan perhitungan butir soal. Analisis ini dilakukan pada siswa kelas IX.3 SMP Negeri 17 Palembang yang berjumlah 38 orang. Perhitungan validasi butir soal digunakan rumus Pearson product moment. Untuk perhitungan reliabilitas dalam penelitian ini digunakan rumus $\alpha$. Dari perhitungan tersebut diperoleh 12 soal yang valid sebagaimana ditunjukkan pada Tabel 4.5 di bawah ini

Tabel 4.5. Hasil uji validasi terhadap soal pada prototype II

\begin{tabular}{|c|c|c|c|}
\hline Nomor Soal & r-tabel & r-hitung & Keterangan \\
\hline 1 & 0,320 & 0,425 & Valid \\
\hline 2 & 0,320 & 0,631 & Valid \\
\hline 3 & 0,320 & 0,641 & Valid \\
\hline 4 & 0,320 & 0,639 & Valid \\
\hline 5 & 0,320 & 0,598 & Valid \\
\hline 6 & 0,320 & 0,678 & Valid \\
\hline 7 & 0,320 & 0,370 & Valid \\
\hline 8 & 0,320 & 0,616 & Valid \\
\hline 9 & 0,320 & 0,753 & Valid \\
\hline 10 & 0,320 & 0,707 & Valid \\
\hline 11 & 0,320 & 0,807 & Valid \\
\hline 12 & 0,320 & 0,880 & Valid \\
\hline
\end{tabular}

Sedangkan untuk koefisien realibilitas dari soal-soal prototype II diperoleh nilai sebesar 0,871 . Sesuai dengan kriteria reabilitas yang telah ditetapkan sebelumnya, maka nilai tersebut menunjukkan bahwa soal matematika model PISA konten quantity untuk mengukur kemampuan pemecahan masalah memiliki realibilitas sangat tinggi.

\section{- Uji Coba Small Group}

Soal-soal yang telah direvisi berdasarkan experts review dan one-to-one dinamakan dengan prototype II. Soal-soal tersebut diujicobakan pada small group yang terdiri dari 6 orang siswa 
JURNAL GANTANG. Maret 2017; II(1): 63 - 77

p-ISSN. 2503-0671

e-ISSN. 2548-5547

SMP Negeri 17 Palembang dengan kemampuan berbeda. Dalam pelaksanaan small group, peneliti juga mengamati siswa ketika mengerjakan soal-soal yang diberikan. Berbeda dengan uji coba one-to-one, pada tahap ujicoba small group intensitas siswa bertanya tentang maksud soal atau kalimat soal sudah berkurang.

Berdasarkan uji validitas butir soal serta komentar dan saran siswa pada small group maka peneliti mengambil tindakan dan keputusan langkah tindakan revisi sebagaimana diuraikan pada Tabel 4.6 berikut:

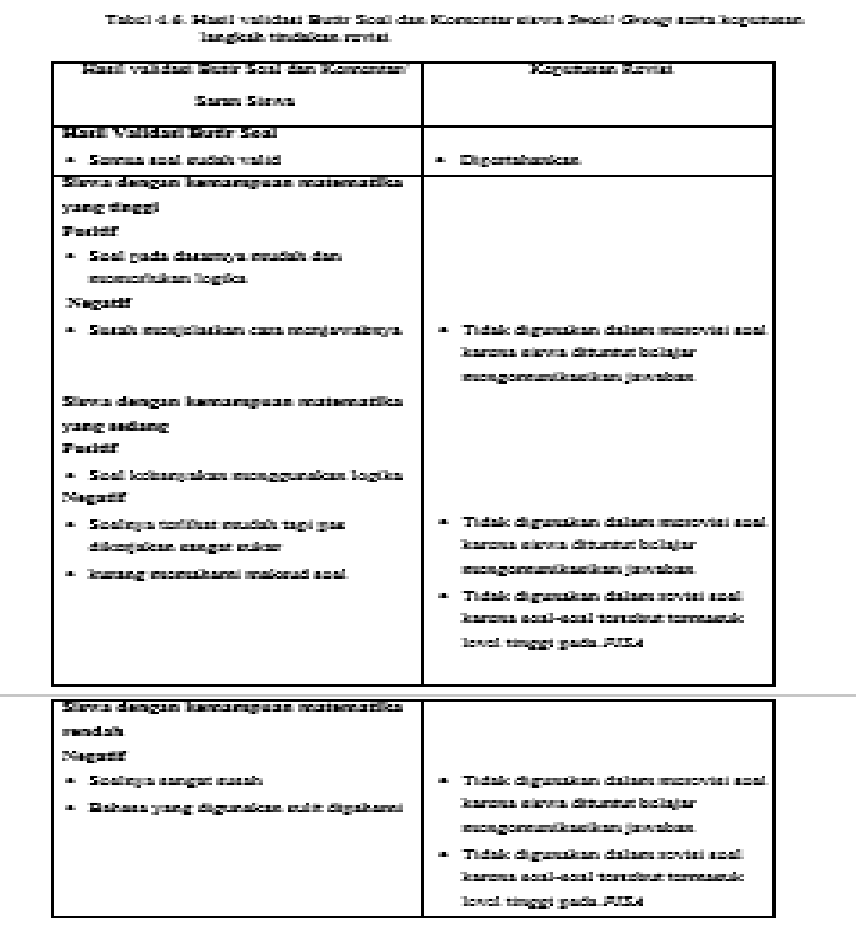

Berdasarkan Tabel 4.6, hasil revisi soal terhadap analisis butir soal (validasi butir soal) dan saran/komentar siswa pada small group sebagaimana diuraikan di atas menghasilkan prototype III yang terdiri dari 12 soal yang akan diuji pada field test.

- Field Test (Uji Lapangan)

Pada tahap ini, soal-soal matematika model PISA pada prototype III akan diujikan pada subjek penelitian yaitu siswa kelas IX.2 SMP Negeri 17 Palembang.
A. Deskripsi Pelaksanaan Uji Coba (Field Test)

Uji coba lapangan (field test) dilakukan di kelas IX.2 SMP Negeri 17 palembang dengan jumlah siswa sebanyak 36 siswa yang terdiri dari 15 siswa laki-laki dan 21 siswa perempuan. Field test ini bertujuan untuk mengetahui efek potensial soal matematika model PISA pada konten quantity terhadap kemampuan pemecahan masalah matematika siswa khususnya potensi siswa dalam pemecahan masalah.

B. Deskripsi Analisis Data Tes Soal PISA pada Konten Quantity untuk mengukur kemampuan pemecahan masalah

Data hasil tes soal PISA pada konten quantity dianalisis untuk menentukan persentase rata-rata nilai akhir siswa yang selanjutnya dikonversikan ke dalam data kualitatif untuk menentukan kategori tingkat kemampuan pemecahan masalah matematika siswa. Adapun persentase tingkat kemampuan pemecahan masalah matematika siswa kelas field test terhadap 12 soal tersebut, dapat dilihat pada Tabel 4.7 sebagai berikut:

Tabe1 4.7. Distribusi Skor rata-rata kemampuan pemecahan masalah matematika siswa
\begin{tabular}{|c|c|c|c|}
\hline Interval Nilai & Frekuensi & Persentase (\%) & Kategori \\
\hline $76-100$ & 2 & 5,56 & Sangat Baik \\
$51-75$ & 16 & 44,44 & Baik \\
$26-50$ & 10 & 27,78 & Cukup \\
$0-25$ & 8 & 22,22 & Kurang Baik \\
Jumlah & 36 & 100 & \\
\hline \multicolumn{2}{|c|}{ Rata-Rata } & 54,64 & Baik \\
\hline
\end{tabular}

Berdasarkan Tabel di atas, dapat dilihat bahwa soal-soal yang telah dikembangkan dapat menunjukkan/mengukur kemampuan pemecahan masalah siswa sekolah menengah pertama. Informasi dari Tabel menunjukkan bahwa kemampuan pemecahan masalah matematika siswa kelas field test tersebar dalam 4 kategori. Secara klasikal diperoleh bahwa kemampuan siswa dalam menyelesaikan soal-soal model PISA konten quantity untuk mengukur kemampuan pemecahan masalah masih berada dalam kategori baik.

C. Pembahasan

Proses pengembangan soal yang terdiri dari tiga tahap yaitu self evaluation, prototyping 
(expert reviews, one-to-one, small group) dan field test serta revisi pada masing-masing tahap ini telah menghasilkan seperangkat soal matematika model PISA pada konten quantity yang valid dan praktis. Soal tersebut dinyatakan valid setelah melalui proses validasi dari beberapa validator yang telah memberikan kontribusi berupa saran dan komentar terhadap perbaikan soal baik dari segi konten (sesuai dengan ciri PISA, indikator kemampuan pemecahan masalah), konstruks (mengembangkan kemampuan pemecahan masalah, kaya dengan konsep, sesuai dengan level siswa SMP kelas IX SMP), dan bahasa (sesuai dengan EYD, soal tidak berbelit-belit, soal tidak mengandung penafsiran ganda, dan jawaban jelas). Setelah soal dinyatakan valid secara kuantitatif berdasarkan konten, konstruk, dan bahasa kemudian soal diujicobakan terhadap siswa kelas IX.3 SMP Negeri 17 Palembang sebanyak 38 siswa untuk menganalisis validasi butir soal dan realibilitas soal. Dari hasil analisis butir soal tersebut diperoleh semua soal (12 soal) yang valid dengan koefisien realibilitas $\mathrm{r} 11=$ 0,871 (realibilitas tinggi).

Dari hasil revisi berdasarkan komentar/saran siswa pada one-to-one dan small group evaluation menunjukkan bahwa soal yang dikembangkan praktis. Soal tersebut dikategorikan praktis tergambar dari hasil pengamatan pada uji coba small group, dimana semua siswa dapat menggunakan perangkat soal dengan baik. Hal ini menujukkan bahwa soal yang dikembangkan sesuai dengan alur pikiran, konteks yang diberikan/diketahuBerdasarkan hasil tes dan wawancara dengan siswa, diketahui bahwa soal-soal matematika model PISA konten quantity untuk mengukur kemampuan pemecahan masalah yang dikembangkan bisa menggali potensi matematis siswa. Siswa tidak hanya sekedar memiliki pengetahuan tetapi lebih dari itu. Mereka menggunakan pengetahuan tersebut dalam memecahkan masalah berupa soal-soal yang merupakan aplikasi dari kehidupan nyata. Ada siswa yang mampu memahami soal dengan baik, mampu menjawabnya dengan benar dan memberikan penjelasan untuk menjawabnya. Ada juga yang mampu memahami soal dan merencanakannya dengan benar namun sulit untuk melakukan penyelesaiannya. Selain itu, juga terdapat siswa yang tidak bisa mengerjakan karena tidak memahami soal.

\section{Penutup}

Dari Penelitian ini telah menghasilkan suatu produk pengembangan soal matematika sehingga dapat disimpulkan sebagai berikut:

1. Penelitian ini telah menghasilkan suatu produk soal matematika model PISA pada konten quantity untuk siswa kelas IX SMP yang valid dan praktis. Valid tergambar dari hasil penilaian validator, dimana semua validator menyatakan sudah baik berdasarkan konten (sesuai kompetensi dasar, dan indikator), konstruk (sesuai dengan teori dan kriteria soal PISA), dan bahasa (sesuai dengan kaidah bahasa yang berlaku dan EYD). Selain itu kevalidan soal model PISA ini tergambar setelah dilakukan analisis validasi butir soal pada kelas uji coba sebelum diadakan field test. Praktis tergambar dari hasil uji coba small group dimana sebagian besar siswa dapat menyelesaikan soal model PISA pada konten uncertainty yang diberikan.

2. Berdasarkan proses pengembangan diperoleh bahwa prototype soal model PISA pada konten quantity yang dikembangkan memiliki efek potensial yang positif terhadap kemampuan pemecahan masalah matematika siswa, walaupun efek potensial tersebut $54,64 \%$ siswa menguasai kemampuan pemecahan masalah matematika. Ini berarti bahwa siswa memiliki potensi untuk mengembangkan pengetahuan mereka sendiri sehingga ada efek potensial.

Berdasarkan hasil penelitian dan kesimpulan, maka disarankan:

1. Guru matematika hendaknya menggunakan perangkat soal matematika model PISA konten quantity yang telah dibuat sebagai alternatif dalam perbaikan evaluasi pembelajaran sehingga dapat digunakan untuk melatih kemampuan pemecahan masalah matematika siswa. 
2. Peneliti lain dapat sebagai bahan masukan untuk mempelajari mendalam mengenai soalsoal matematika

3. Siswa dapat melatih menggunakan pengetahuan yang dimilikinya untuk menjawab soal-soal matematika model PISA.

\section{Daftar Pustaka}

Arikunto, S. (1999). Dasar-dasar evaluasi pendidikan. Jakarta: Bumi Aksara.

Depdiknas. (2005). Peraturan pemerintah Republik Indonesia Nomor 19 tahun 2005 tentang Standar Pendidikan Nasional . Jakarta: Depdiknas.

(2006). Peraturan pemerintah Republik Indonesia Nomor 23 tahun 2006 tentang Standar Isi mata pelajaran matematika. Jakarta: Depdiknas.

Djaali dan Mulyono P.(2008). Pengukuran dalam Bidang Pendidikan. Jakarta: Grasindo.

Econtentplus. (2009). Target Competencies. Europe: Math Bridge Program.

Harini, F. L. (2006). Keefektifan Model Pembelajaran Kooperatif Tipe Jigsaw terhadap Kemampuan Pemecahan Masalah Siswa Kelas VII SMPN 1 Wonosobo Tahun Pelajaran 2005/2006 pada Pokok Bahasan Segiempat. Skripsi Jurusan Matematika FMIPA UNNES.

Hayat,B. dan Yusuf, S. (2010). Bencmark: Internasional Mutu pendidikan. Jakarta: Bumi Aksara.

Julaiha, Ellah. (2011).Pengembangan Soal Matematika Tipe PISA yang menggunakan Konteks Sumsel Tingkat SMP. Tesis Jurusan Matematika UNSRI.

NCTM. (2000). Principles and Standards for School Mathematics. Reston: NCTM. . (2010). Why Is Teaching With Problem Solving Important to Student Learning. Reston:NCTM.

OECD. (2000). Programme for Intrnational students assessment: sample tasks from the PISA 2000 Assesment of reading, mathematical and scientitific literacy (online). http:www.oecd.org/dataoecd/61/15/4624

1909.pdf (diakses 10 Januari 2012). (2003). PISA 2003 Assesment Framework(online).

http:www.oecd.org/dataoecd/11/40/444 55820.pdf (diakses 10 Okteober 2011). . (2006). Programme for Intrnational students assessmen (PISA). (online).

http:www.oecd.org/dataoecd/61/15/462 41909.pdf (diakses 10 Januari 2012).

. (2009). PISA 2009 Assesment Framework(online).

http:www.oecd.org/dataoecd/11/40/444 55820.pdf (diakses 10 Oktober 2011). . (2010). Drfat PISA 2012 Assesment

Framework (online) http:www.oecd.org/dataoecd/61/15/462 41909.pdf (diakses 10 Januari 2012).

Sudjana. (2002). Metode statistika. Bandung: Tarsito.

Sugiyono. (2007). Statistika untuk penelitian. Bandung: Alfabeta.

Tessmer. (1993). Planning and Conducting Formative Evaluation. London: Kogan Page.

Usman, S. (2007). Strategi pemecahan masalah dalam penyelesaian soal cerita disekolah. Jurnal Samudra Ilmu 2007, Volume 2 Nomor Q.luni 12007 ISSN .19Q7-199X.

Unsri. (2010). Buku Pedoman Program Pascasarjana Universitas Sriwijaya Tahun 2009. Palembang: PPs Universitas Sriwijaya.

Van den Akker, J. (1999). Principles and Methods of development Research. Dalam J.v.d Akker (Ed). Desaign Approaches and Tools in Education and Training. Dordrecht: Kluwer Academic Publishers.

Wardhani, Sri. (2005). Pembelejaran dan penilaian aspek pemahaman konsep, penalaran, dan komunikasi, pemecahan masalah. Jogyakarta: materi pembinaan matematika SMP di daerah tahun 2005 (PPPG Matematika). 
(2011). Instrumen Penilaian Hasil

Belajar Matematika SMP: Belajar dari PISA dan TIMSS. Yogyakarta.

Yosita, Silva Evy. (2011). Pengembangan Soal Matematika Model PISA pada konten Uncertainty untuk mengukur kemampuan Pemecahan Masalah Matematika Siswa Sekolah Menengah Pertama.Tesis Jurusan Matematika UNSRI.

Zulkardi. (2006). Formative Evaluation; what, why, when, and how. (online: diakses tanggal 19 Oktober 2010 di www.geocities.com/Zulkardi/books.ht $\mathrm{ml}$ ) 
JURNAL GANTANG. Maret 2017; II(1): 63 - 77

p-ISSN. 2503-0671

e-ISSN. 2548-5547 